\title{
Emergence of Corporate Philanthropy: Chapter Bangladesh
}

\section{Md. Shahriar Parvez}

Lecturer, Department of Business Administration, City University, Bangladesh

\begin{abstract}
The study objective is to focus on emergence of corporate philanthropy on Bangladesh. Corporate philanthropy is a phenomenon which associates the business sector with the social sector. Social historians and researchers alike as a subset of a larger corporate social responsibility (CSR) subject, philanthropy provides an opportunity for corporations to establish an ethical and moral mantra within the organization. The study also aims to find out, understand the perspective of attributes, legal context, importance, advantages and disadvantages, competitive advantage, Sectors contribution analysis of emergence of corporate philanthropy on Bangladesh. The study used published secondary source of data from various relevant sources reports, websites, journals, publications and the researcher have used own personal experience regarding the country's corporate behavior and following background and their impact on this research paper. After conceptualizing the various situations and literatures review the study find out that corporate philanthropy is a new concept in the corporate world and increasing clients/customers demand on the products and services towards the corporate in the meantime cooperate responsibilities towards their clients/ customers also increasing day by day, so emergence of the corporate philanthropy in Bangladesh is a vital part of the corporate sector and Bangladeshi business culture for centuries and it seems that an emphasis on charitable contributions from philanthropic programs has enhanced the visibility of this practice in Bangladesh.
\end{abstract}

Keywords: Corporate Philanthropy, Community Benefits, Corporate Social Responsibility, Company Image, Community Support and Market Creation.

\section{GEL Classification Code: M14; N30}

\section{INTRODUCTION}

According to Philip L. Fioravante (2008) research paper, corporate philanthropy is a phenomenon which associates the business sector with the social sector. Social historians and researchers alike as a subset of a larger corporate social responsibility (CSR) subject, philanthropy provides an opportunity for corporations to establish an ethical and moral mantra within the organization (Gan, 2006; Madr igal \& Boush, 2008). An organization is comprised of people who assume the responsibility of cultivating and maintaining a 
culture supportive of philanthropy and its range of objectives. Successful philanthropy achieving the goal is as vita 1 to an organization as the "core business" (Bruch \& Walter, 2005). Philanthropic initiatives are complex and thus need to be developed, communicated, implemented, monitored, and lastly sustained, in order to guarantee its viability as a strategic tool.

Corporate philanthropy, where a corporation donates a portion of its resources to a societal cause, has been an important part modern business corporation. Today it is examined that most of the famous and non famous corporation of the world that some amount of funds donated underscores the importance today's corporations place on philanthropic activity. Philanthropy is defined as a means by which public organizations externally exhibit corporate social responsibility - widely defined by a myriad of scholarly authors (Carroll, 1979; Gan, 2006; Halme \& Laurila, 2009). Corporate philanthropy, where a corporation donates a portion of its resources to a societal cause, has been an important part modern business corporation. Today it is examined that most of the famous and non famous corporation of the world that some amount of funds donated underscores the importance today's corporations place on philanthropic activity. Corporate Philanthropy mirrors individual philanthropy except for the fact that a corporation, not an individual, is donating funds, time, or talent. Although done on a larger scale, corporate philanthropy is still done without any expectation of direct corporate gain such as increases in revenue, but usually involves indirect gains such as enhancing a company's brand, engaging employees, recognition, etc.

Corporate philanthropy is a phenomenon which associates the business sector with the social sector. Social historians and researchers alike as a subset of a larger corporate social responsibility (CSR) subject, philanthropy provides an opportunity for corporations to establish an ethical and moral mantra within the organization. An organization is comprised of people who assume the responsibility of cultivating and maintaining a culture supportive of philanthropy and its range of objectives. Successful philanthropy achieving the goal is as vital to an organization as the core business. Philanthropic initiatives are complex and thus need to be developed, communicated, implemented, monitored, and lastly sustained, in order to guarantee its viability as a strategic tool.

There can be internal institutional benefits as well. Increased interaction between staff of corporate giving units and business divisions can help build understanding within the company of how it can address the often complex social issues that exist in various places within their global market. The emergence of a cadre of personnel with experience in both fields is likely to further encourage cross-fertilization of ideas and skills. While many companies have long-standing philanthropy programs, many have begun to apply business thinking and models to their philanthropic objectives. For a growing number of firms, philanthropy is no longer developed separately from corporate strategy. The issues that companies target for financial support are increasingly aligned with corporate risk management and bottom-line objectives.

\section{Purpose}

Corporate philanthropy, where a corporation donates a portion of its resources to a societal cause, has been an important part modern business corporation. Today it is examined that most of the famous and non famous corporation of the world that some amount of funds donated underscores the importance today's corporations place on philanthropic activity. The study focuses on emergence of corporate philanthropy on 
Bangladesh. Corporate philanthropy is a phenomenon which associates the business sector with the social sector. Social historians and researchers alike as a subset of a larger corporate social responsibility (CSR) subject, philanthropy provides an opportunity for corporations to establish an ethical and moral mantra within the organization. This paper also aims at understanding the perspective of attributes, legal context, importance, advantages and disadvantages, competitive advantage, Sectors contribution analysis of emergence of corporate philanthropy on Bangladesh.

\section{Methodology}

The study uses secondary data collected mainly from the various published documents, office circular, official web folders other related websites, journals, publications etc. all information and reference is provided in the reference section of this research paper. In addition to this the researcher has used personal observation and experience regarding the country's socio economic and corporate sectors and their impact and standpoint of emergence corporate philanthropy on Bangladesh.

\section{Literature Review}

Many types of research articles, based on analytical, empirical, qualitative and mixed methods approaches inquisitive about CSR (corporate social responsibility) now authors innovate the new phenomenon of "Philanthropy" as a subset of CSR (corporate social responsibility). According to Friedman (1970) showed his self-professed communalist propensity and his theories concerning market mechanisms, capita 1 structure, and the conception of social responsibility. His hypothetical spot centered on the word "social" and concluded, "There are no 'social' values, no 'social' responsibilities in any sense other than the public values and responsibilities of individuals" (p.126). This perspective may initially appear to have a positivist paradigm. However, Friedman (1970) later asserted there is a association between the company and the consumer in an economic sense that drives the rules the rendezvous in an open, free of fraud, and responsible manner. Corporate social responsibility as evidenced continues to play a role in the strategic direction and financial performance of a company. The economic aspects have reasonable correlation to positive market presence and therefore consumer perception. In addition, these perceptions and the extent of CSR exhibited by a company affect buying behaviors (Bird, Hall, Momentè \& Reggiani, 2007; Lockett, Moon \& Visser, 2006). Continuing, Lockett et al. (2006) stated, "A though CSR [philanthropy] is addressed by many disciplines [it] has become an increasingly salient feature of business and the environment, to which managers are expected to respond" (p. 115). Agreeing with this postulation creates the further opportunity to study cause and effect variables such as brand strategy and how it is affected by philanthropic initiatives employing a qualitative (phenomenological) design study. According to Philip L. Fioravante (2008) social sciences such as sociology and psychology contribute to ethical decision-making, consumer perceptions and brand loyalty. Data analysis within case studies and interviews have provided clear correlations between CSR [philanthropy] and "marketing" objectives such as revenue generation, market share, brand reputation, and market differentiation. Understanding the potential impact of philanthropy in all of its forms enables a corporation to alter its value proposition and ultimately shape the manner in which it employs this phenomenon in the business strategy. Strategic marketing has a myriad of meanings and applications across industries. Philanthropy can add altruistic and capitalistic contribution to an organization. By analyzing how corporations use 
philanthropy for strategic marketing purposes, conclusions are possible that are drawn on the deep value beyond the "feel good" and towards a business growth driver.

\section{Attributes of Corporate philanthropy}

- Like standard philanthropy, corporate philanthropy focuses on the treating the cause of a problem or issue instead of the symptom.

- Unlike standard philanthropy, corporate philanthropy must be done through a corporation directly or a corporation's own non-profit entity.

- $\quad$ Funding for corporate philanthropy mainly comes from the company's contributions and is usually treated as a business expense.

- Funding can also consist of individual donations if, for example, someone wanted to donate to a corporation's non-profit.

- Companies are allowed to deduct up to ten percent of pre-tax income for direct charitable contributions - this includes giving to the company's foundation. Most companies deduct closer to one percent.

- Some of the common forms of corporate philanthropy are:

- Cash donations: including grants, donations, sponsorships - whenever money exchanges hands.

- In-kind donations: such as donating products, access to employee volunteer groups, the use of a company's facilities, property, or services as examples whenever non-monetary support is given.

These are some basic attributes discussed in above. It is not framed within these small characteristics. The days are passing and new corporation build up. So, new concept of philanthropy is introduced in corporate sector. Because in the era of modern evolution of Corporate Social Responsibility (CSR).

\section{The legal context of corporate philanthropy and law in Bangladesh}

The concept of philanthropy in Bangladesh is rooted in custom, tradition and religion. Philanthropy in Bangladesh has transcended generations and spanned communities. Influenced by an amalgam of cultures derived from Hinduism, Buddhism, Christianity and Islam, Bangladesh has a rich and traditional heritage manifest in its diverse customs, art, literature, music and people's way of life.

Throughout Bangladesh's history, the practice of giving to others without expecting any return and helping the distressed often began at home and formed a crucial part of the socialization process in which family values and traditions were instilled in young people. These activities had both voluntary and religious dimensions.

Over time, individuals and groups in Bangladesh undertaking philanthropic initiatives have worked to incorporate professionalism and expertise through organizational and management structures to make their work more sustainable. Therefore, what started out as a purely humanitarian effort has evolved into concrete mechanisms for providing services to the public. To these end societies, trusts, clubs, associations, foundations and other entities were established with the primary objective of rendering social services. More recently, the Bangladeshi business community and corporations has also been engaged in social welfare activities. Well-established corporate bodies have engaged in nonprofit welfare activities ranging from job creation to providing education and medical care. 
The Ispahani Group for example, a prominent business house, is well known for its charitable activities and specifically an eye hospital. Corporate donors and employers associations have also established schools to train child laborers following U.S. pressure on the child labor industries. Yet while there is a great deal of potential for corporate philanthropy activities, contributions from business enterprises to charitable activities remain negligible.

\section{Why corporate philanthropy in Bangladesh?}

The corporate philanthropy has a long history in Bangladesh. These philanthropic activities included donations to different charitable organizations, poor people and religious institutions. Till now, most of the businesses in Bangladesh are family owned and first generation businesses. They are involved in community development work in the form of charity without having any definite policy regarding the expenses or any concrete motive regarding financial gains in many instances.

The discussions on corporate philanthropy practices in Bangladesh in its modern global terms, are relatively new, but not so for the concept itself. Because, being a part of the global market, it is difficult to ignore philanthropy standard specifically in the export sector.

In general, it is true that in Bangladesh, the status of labor rights practices, environmental management and transparency in corporate governance are not satisfactory, largely due to poor enforcement of existing laws and inadequate pressure from civil society and interest groups like Consumer Forums.

Globally, as philanthropy practices are gradually being integrated into international business practices and hence is becoming one of the determining factors for market accesses, it is becoming equally instrumental for local acceptability. A focus on CSR in Bangladesh would be useful, not only for improving corporate governance, labor rights, work place safety, fair treatment of workers, community development and environment management, but also for industrialization and ensuring global market access.

\section{The Importance of corporate philanthropy in Bangladesh}

Corporate philanthropy in Bangladesh ranges from financial contributions to employees volunteering time on the clock. While philanthropy costs the company, it also provides benefits for the company, community and employees. Understanding the significance of corporate philanthropy helps each company justify the expense to upper management and investors.

Community Benefits: No matter what the motivation for corporate philanthropy, the community and specific organizations helped through the program benefit. When a company offers financial support, local organizations are able to afford supplies and programs that might otherwise go unfunded. These benefits for the recipients of the philanthropic efforts strengthen the community as a whole. Depending on the specific help offered by a corporation, the efforts may result in a cleaner community, more opportunities for residents and a boost to the local economy.

Morale: Companies who emphasize public service and volunteerism may notice a boost in morale, particularly if the employees value the idea of giving back to the community. Employees who work together on a charity project gets to know one another beyond the typical scope of work. The work may even improve teamwork on work projects. When companies of Bangladesh allow employees to volunteer during the work day, you show them that the company cares about the community and emphasizes a sense of giving. 
Recruitment: In Bangladesh most employees want to do philanthropic work. Establishing each company in Bangladesh as a philanthropic company gives the company a potential edge when recruiting new employees. Job seekers who see that financial giving is part of the company culture are likely to see that as a positive for the company. Individuals who already volunteer, work with charities and do other philanthropic work on their own are particularly likely to be drawn to a company with the same values. The company's philanthropic efforts give you one more bullet point to add to recruitment information.

Company Image: As news of the company's philanthropy spreads, the community develops an impression of the company. People tend to view philanthropic businesses favorably because they are supporting the community that provides them with business. In some cases, this positive image encourages community members to utilize company's services over a competitor who fails to become involved with the community. To maintain a positive company image, the philanthropic efforts need to be helpful and done primarily for the benefit of the recipients. By arranging some philanthropic works companies of Bangladesh can build their company's image throughout the world.

\section{Advantages and Disadvantages of Corporate philanthropy in Bangladesh}

Corporate philanthropy is a general term for the actions that businesses take to improve their communities and society in general. Corporate philanthropy can include donations of money or of time and labor at community centers or for improvement projects, or for fundraising for a cause. There are both clear advantages to corporate philanthropy, as well as a disadvantage.

Community Support and Market Creation: A major advantage that companies gain from their philanthropic practices is the support of communities and the surrounding markets. Essentially, by using profits derived from the community to benefit that same community businesses can greatly increase their prospects of future revenue flows.

Market Development through Reputation: Market development can also occur through the improved reputation of the business. The goodwill that a company can generate through corporate philanthropy can increase customer's interest and favorable opinions of the company. This may lead to increased sales, especially when the philanthropy is combined with effective advertising and co-branding.

Direct Giving can hamper Goals: On the other side direct philanthropy created through pure donations of money can make it difficult for a business to actually change what it wants to change. A donation to a nonprofit agency may put control of the funds beyond the reach of the business. There is no guarantee that the agency will improve the community or offer any of the benefits that the business can gain from philanthropy. If we think this in the perspective of Bangladesh than the situation is very dangerous. There are many community agencies are formed in Bangladesh whose main purpose is to undertake some community wealth and uprooted the business in secret. So, this makes a bad impression about philanthropic work by the business community.

Time, Cost, and Decisions: If a corporation decides and invest money in the community itself, then there are other disadvantages. The business must form a team and decide how much money to give and where it should be given to produce the most impact. Decisions affect not only the length of the project, but also any marketing that goes along with it. In 
the end, the company must be prepared to spend time, money and decision-making power on a project that has no direct benefits.

\section{The competitive advantage of Corporate philanthropy}

When it comes to philanthropy, executives increasingly see themselves as caught between critics demanding ever higher levels of corporate social responsibility and investors applying pressure to maximize short-term profits. Increasingly, philanthropy is used as a form of public relations or advertising, promoting a company's image through high-profile sponsorships. But there is a more truly strategic way to think about philanthropy.

Corporations can use their charitable efforts to improve their competitive context--the quality of the business environment in the locations where they operate.

Using philanthropy to enhance competitive context aligns social and economic goals and improves a company's long-term business prospects. Addressing context enables a company not only to give money but also leverage its capabilities and relationships in support of charitable causes. Taking this new direction requires fundamental changes in the way companies approach their contribution programs. Adopting a context-focused approach requires a far more disciplined approach than is prevalent today. But it can make a company's philanthropic activities far more effective.

\section{Corporate philanthropy is on the top of CRS hierarchy}

\section{The Hierarchy of Corporate Responsibilities}

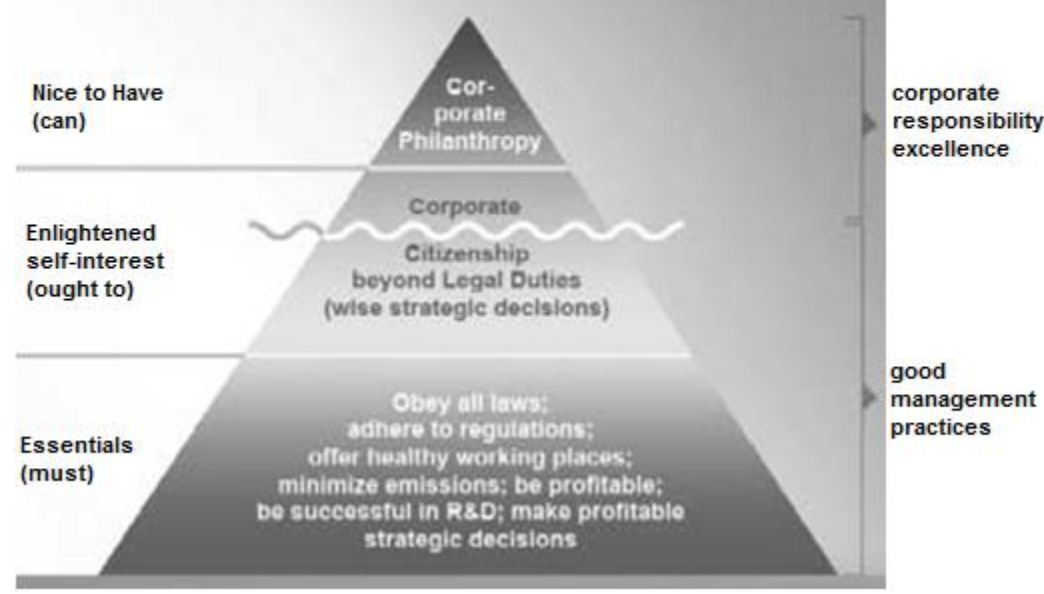

Source: Google Image.

\section{Sectors contributing in philanthropy in Bangladesh}

Many corporations of Bangladesh have come forward to arrange philanthropic work. Bangladesh is a developing country and it is properly understood by different companies in Bangladesh. So, they are come together in arranging a campaign of philanthropy. Donation of different charitable funds, helping poor and affected people, providing scholarship for students, make different initiatives funds etc. The Banking Sector continues to make the largest 
contribution to philanthropy in Bangladesh as their corporate philanthropy. The Commercial Banks directed and encouraged by the Bank of Bangladesh have made cash donations to individuals and projects in a wide variety of sectors. Trade Associations such as BGMEA and BKMEA and the International Brands sourcing from Bangladesh garment factories have set up training centers, work place day nurseries and have welfare funds, worker insurance schemes and education and cultural activities as part of their corporate philanthropy.

\section{Conclusion}

Corporate philanthropy involves members of corporations taking responsibility for the society but it also expects people who have more resources and more influence to use their privileged position to help those who are less well off. While the phenomenon of philanthropy has been a necessary part of Bangladeshi business culture for centuries, it seems that an emphasis on charitable contributions from philanthropic programs has enhanced the visibility of this practice. By understanding and the importance of corporate philanthropy one of the Government Ministries should devise a 'world-class' Bangladesh specific definition of corporate philanthropy and a Bangladesh philanthropic Policy. However, the principal motivation of Bangladeshi firms to engage in philanthropic activities has stemmed from a sense of their moral obligation to give back to society as businesses control a bulk of society's resources and the financial inability of the government to fix social problems.

\section{REFERENCES}

Bird, R., Hall, A., Momentè, F., \& Reggiani, F. (2007). What corporate social responsibility activities are valued by the market? Journal of Business Ethics, 76(2), 189-206.

Bruch, H. \& Walter, F. (2005). The keys to rethinking corporate philanthropy. MIT Sloan Management Review, 47(1), 49- 55.

Carroll, A. (1979). A three-dimensional mode 1 or corporate performance. Academy of Management Review, 4(4), 497-505.

Friedman, M. (1970, September 13). The social responsibility of business is to increase its profits. TheNew York Times Magazine, 32-33, 122, 124, 126.

Gan, A. (2006). The impact of public scrutiny on corporate philanthropy. Journal of Business Ethics, 69(3), 217-236.

Hamle, M. \& Laurila, J. (2009). Philanthropy, integration or innovation? Explor ing the financial and societal outcomes of different types of corporate responsibility. Journal of Business Ethics, 84(3), 325-339.

Madrigal, R., \& Boush, D. (2008). Social responsibility as a unique dimension of brand personality and consumers' willingness to reward. Psychology \& Marketing, 25(6), 538-564.

Philip L. Fioravante (2008). Corporate Philanthropy: A Strategic Marketing Consideration. Journal of Applied Business and Economics vol.11 (3)

\section{Web Site References}

http://smallbusiness.chron.com/advantages-disadvantages-corporate-philanthropy-23965.html http://www.isc.hbs.edu/soci-corporate_philanthropy.htm

http://exectimes.com/content/apr12/CSR.asp

http://www.kantakji.com/fiqh/Files/Companies/z120.pdf 
https://www.ammado.com/nonprofit/105776/articles/9858

http://www.isc.hbs.edu/soci-corporate_philanthropy.htm

http://www.google.com

www.na-businesspress.com/JABE/FiorvanteWeb.pdf

www.corporatephilanthropy.org/pdfs/.../MVCP_report_singles.pdf

www.fdp.hse.ru/data/.../Oct\%2028\%20Paul\%20C.\%20Godfrey.pdf

http://www.hudson.org/files/documents/BradleyCenter/Kristol_On_Corporate_Philanthropy.pdf

\section{Appendix A}

\section{Bangladesh Economy}

The economy has grown 5-6\% over the past few years despite inefficient state-owned enterprises, delays in exploiting natural gas resources, insufficient power supplies, and slow implementation of economic reforms. Bangladesh remains a poor, overpopulated, and inefficiently-governed nation. Although more than half of GDP is generated through the service sector, nearly two-thirds of Bangladeshis are employed in the agriculture sector, with rice as the single-most-important product. Garment exports and remittances from Bangladeshis working overseas, mainly in the Middle East and East Asia, fuel economic growth.

\begin{tabular}{|c|c|}
\hline GDP: & $\$ 208.3$ billion (2007 est.) \\
\hline GDP growth rate: & $6.3 \%$ \\
\hline GDP per capita: & $\$ 1,400$ \\
\hline GDP composition by sector: & agriculture: $19 \%$; industry: $28.7 \%$; services: $52.3 \%$ \\
\hline Labor force: & $\begin{array}{l}66.6 \text { million } \\
\text { note: extensive export of labor to Saudi Arabia, Kuwait, UAE, Oman, Qatar, } \\
\text { and Malaysia; workers' remittances estimated at } \$ 1.71 \text { billion in 1998-99 }\end{array}$ \\
\hline Labor force by occupation: & agriculture: $63 \%$; industry: $11 \%$; services: $26 \%$ \\
\hline Unemployment: & $2.5 \%$ (includes underemployment) \\
\hline Budget: & $\begin{array}{l}\text { revenues: } \$ 5.993 \text { billion } \\
\text { expenditures: } \$ 8.598 \text { billion }\end{array}$ \\
\hline Industries: & $\begin{array}{l}\text { cotton textiles, jute, garments, tea processing, paper newsprint, cement, } \\
\text { chemical fertilizer, light engineering, sugar }\end{array}$ \\
\hline $\begin{array}{l}\text { Electricity production by } \\
\text { source: }\end{array}$ & fossil fuel: $93.7 \%$; hydro: $6.3 \%$; nuclear: $0 \%$; other: $0 \%$ \\
\hline Agriculture: & $\begin{array}{l}\text { irice, jute, tea, wheat, sugarcane, potatoes, tobacco, pulses, oilseeds, spices, } \\
\text { fruit; beef, milk, poultry }\end{array}$ \\
\hline Exports: & garments, jute and jute goods, leather, frozen fish and seafood \\
\hline Export partners: & US $24.2 \%$, Germany $13.2 \%$, UK $10.6 \%$, France $6 \%$ \\
\hline Imports: & $\begin{array}{l}\text { machinery and equipment, chemicals, iron and steel, textiles, foodstuffs, } \\
\text { petroleum products, cement }\end{array}$ \\
\hline Import partners: & $\begin{array}{l}\text { India } 14.7 \% \text {, China } 14.6 \% \text {, Kuwait } 8 \% \text {, Singapore } 6 \% \text {, Japan } 4.4 \% \text {, Hong } \\
\text { Kong } 4.1 \%\end{array}$ \\
\hline Economic aid recipient: & $\$ 1.575$ billion \\
\hline Currency: & taka (BDT) \\
\hline
\end{tabular}

SOURCES: The CIA World Fact book, U.S. Department of State, Area Handbook of the US Library of Congress. 